\title{
Autoimmune haemolytic anaemia in a child with MHC class II deficiency
}

\author{
G Horneff, R C Seitz, V Stephan, V Wahn
}

\begin{abstract}
A 3 year old Turkish girl is described who was suffering from major histocompatibility complex (MHC) class II deficiency syndrome, which is characterised by the lack of expression of HLA class II antigens on mononuclear cells. The presence of HLA class II genes was demonstrable at the DNA level. Combined immunodeficiency was indicated by hypogammaglobulinaemia and the absence of delayed type hypersensitivity on skin testing. Further, she was unable to produce specific antibodies towards foreign antigens and suffered from recurrent pulmonary, gastrointestinal, and septic infections from the third month of life. The clinical course was complicated by a Coombs test positive haemolytic anaemia due to the production of autoantibodies against the rhesus ' $e$ ' antigen, a non-glycosylated protein antigen. Haemolysis could be controlled by oral steroid treatment. This case is of interest as it shows that despite the absence of HLA class II antigens and combined immunodeficiency autoimmune reactions with production of specific autoantibodies directed to protein antigens are possible. (Arch Dis Child 1994; 71: 339-342)
\end{abstract}

Department of of Düsseldorf G Horneff

V Stephan

V Wahn

Department of Paediatrics, University of Hamburg

R C Seitz

Correspondence to: Dr V Wahn, University Moorenstrasse 5, D-40225 Düsseldorf, Germany.

Accepted 10 June 1994 Paediatrics, University Children's Hospital,
Lymphocyte major histocompatibility complex (MHC) class II deficiency (bare lymphocyte syndrome II) is a rare inborn error characterised by the lack of expression of HLA class II molecules due to defective gene regulation. Absent HLA class I antigen expression was first described by Touraine et al in 1978. ${ }^{1}$ Since then approximately 40 patients have been described with either HLA class I or class II deficiency or with defective expression of both HLA antigens. ${ }^{2-8}$ While MHC class II genes are still detectable at the DNA level, defective expression is probably caused by the absence of a regulatory factor encoded by

addition, IgA deficiency seems to be common. ${ }^{2}$ Surprisingly, in some patients, antibody production to polysaccharides including $A B$ blood group antigens and pneumococcal polysaccharides can be detected. ${ }^{2}$ Therefore an MHC class II independent mode of B cell activation by polysaccharide antigens is likely. Here, we describe a 3 year old girl suffering from bare lymphocyte syndrome II who developed Coombs positive haemolytic anaemia. Surprisingly, the production of autoantibodies specific for the rhesus ' $e$ ' antigen, a non-glycosylated membrane protein, could be demonstrated. ${ }^{12}$

\section{Methods}

Cell preparations, stimulation assays, and immunofluorescence studies were performed according to routine methods previously described. ${ }^{13}$ Immunohaematological investigation of autoimmune haemolytic anaemia included standard plate techniques for ABO, $\mathrm{Rh}$ and Kell blood group typing, using commercially available antisera (Biotest-AG, Frankfurt, Germany, Baxter Dade AG, Düdingen, Switzerland) as well as standard tube techniques for the direct Coombs test. Commercially available monospecific antisera raised in rabbits (anti-IgG, anti-IgA, anti-IgM, anti-C3/C3c, anti-C4, and anti-C3d were purchased from Fresenius, Bad Homburg, Germany and Baxter Dade AG). The differentiation of erythrocyte specific antibodies was performed in saline $\left(4^{\circ} \mathrm{C}, 20^{\circ} \mathrm{C}, 37^{\circ} \mathrm{C}\right)$, and after the addition of albumin $\left(37^{\circ} \mathrm{C}\right)$ by an indirect antiglobulin test using commercially available panel erythrocytes derived from healthy adult donors (Baxter Dade AG). The specificity of membrane bound autoantibodies was characterised using panel cells after acid elution. Additionally, results of antibody identification were checked by the technique of warm alloabsorption: after an incubation of serum samples as well as red cell eluate for 30 minutes at $37^{\circ} \mathrm{C}$, reactivity was specifically removed due to a preferential binding of autoantibodies to the corresponding antigen complex.

HLA class I antigens are expressed on all cells while HLA class II antigens under physiological conditions are only expressed by B cells, monocytes, and activated $\mathrm{T}$ cells. As MHC antigens are involved in the process of presentation of peptides to T cells, ${ }^{10}{ }^{11}$ absence of HLA antigen expression leads to a moderate to severe combined immunodeficiency. In vivo antibody production to infectious agents or vaccines is usually absent leading to increased susceptibility to all types of infections; in

\section{Case report}

A 3 year old girl has suffered from recurrent severe bronchopulmonary and gastrointestinal infections, including one episode of candida sepsis, since the third month of life; some of these episodes required mechanical ventilation for several weeks. Persistent adenovirus pulmonary infection was documented by viral 
Table 1 Immunological findings at 1 year of age

\begin{tabular}{|c|c|c|}
\hline & Patient & Control \\
\hline Lymphocytes/ $\mu 1$ & 4200 & 3800 \\
\hline \multicolumn{3}{|l|}{ Surface markers* } \\
\hline $\mathrm{CD}^{+}{ }^{+}$ & 62 & 85 \\
\hline $\mathrm{CD}^{+}$ & 37 & 45 \\
\hline $\mathrm{CD}^{+}$ & 36 & 38 \\
\hline $\mathrm{CD} 20^{+}$ & 24 & 7 \\
\hline $\mathrm{CD}^{+} 4^{+}$ & 7 & 5 \\
\hline $\mathrm{CD} 3-\mathrm{CD} 56^{+}$ & 8 & 4 \\
\hline $\mathrm{CD}_{18}{ }^{+}$ & 99 & 100 \\
\hline HLA-class $\mathrm{I}^{+}$ & 92 & 95 \\
\hline HLA-DR ${ }^{+}$ & 0 & 15 \\
\hline HLA-DP ${ }^{+}$ & 0 & 5 \\
\hline HLA-DQ ${ }^{+}$ & 0 & 5 \\
\hline
\end{tabular}

$\star$ Per cent positive within lymphocyte and monocyte gate.

culture of bronchoalveolar lavage over a period of more than four months while antibodies to adenovirus, as well as numerous other viral and bacterial antigens, were undetectable. At 10 months, she was referred to our hospital where immunodeficiency was established and characterised by hypogammaglobulinaemia (minimum IgG $1.65 \mathrm{~g} / 1$ at 10 months, minimum IgA $0.08 \mathrm{~g} / 1$ at 8 months; IgM concentrations were normal except for one value of $2.66 \mathrm{~g} / \mathrm{l}$ ) with absence of specific antibodies. All subclasses of IgG were diminished and cutaneous type IV hypersensitivity as assessed by multitest Merieux was absent. T lymphocytopenia was apparent with a decreased CD4/CD8 ratio and an increased proportion of CD20+ B cells (table 1). While expression of adhesion molecules and HLA class I molecules was normal, no HLA class II molecules were found on B cells, monocytes, or stimulated $\mathrm{T}$ cells (figure). HLA typing revealed an HLA A26, A2, B51, and B48 phenotype. Class II antigens could only be typed by DNA analysis. In vitro, mitogen induced lymphocyte proliferation and immunoglobulin production was markedly diminished (table 2). Stimulation in vitro with candida antigen showed a very low response despite the candida sepsis; the responses to purified protein derivative and tetanus toxoid are difficult to interpret because the patient had not been vaccinated.

At 10 months she was started on intravenous immunoglobulin (every four weeks) and cotrimoxazole prophylaxis. Bone marrow transplantation could not be performed because no compatible donor has yet been identified.

At 18 months a Coombs positive haemolytic anaemia was diagnosed with a haemoglobin concentration of $69 \mathrm{~g} / \mathrm{l}$, raised values for reticulocytes, indirect bilirubin, and lactate dehydrogenase; haptoglobin was undetectable. The monospecific antiglobulin test revealed an in vivo binding of IgG and complement $\mathrm{C} 3 \mathrm{~d}$ to the patient's erythrocytes. Warm reactive autoantibodies specific for the rhesus antigen ' $\mathrm{e}$ ' ( $\mathrm{Hr}$ ") were demonstrated in plasma specimens as well as the red cell eluate. The main blood group antigens were typed as $\mathrm{A} R \mathrm{Rh}$ negative ccddee Kell negative, though serum was found to contain trace amounts of low titred 'natural' anti-B. Blood transfusions became necessary and after the immunohaematological diagnosis was established, treatment with steroids ( $2 \mathrm{mg} / \mathrm{kg}$ body weight) was initiated and haemolysis was controlled; the steroid dosage later tapered to an alternate dosage schedule. Surface bound IgG and C3d persisted on erythrocytes and autoreactive antibodies of the IgG isotype with specificity for the rhesus ' $e$ ' antigen remained detectable in serum. Haptoglobin remained low, indicating persisting haemolysis. Haemoglobin concentrations, however, increased to 130 and $140 \mathrm{~g} / \mathrm{l}$ except for a single event of enhanced haemolysis that required an additional transfusion at the age of 28 months. Currently the girl is successfully treated by immunoglobulin replacement every four weeks, co-trimoxazole prophylaxis, and a low dose alternate day steroid regimen ( $4 \mathrm{mg}$ every other day).

\section{Discussion}

Lymphocyte MHC class II deficiency is a rare inherited disorder with combined T/B cell immunodeficiency. ${ }^{1-8}$ Fifteen patients were reported by Griscelli $e t a l^{2}$ and several additional patients have been described. Common immunological features were decreased numbers of circulating $\mathrm{T}$ cells, decreased $\mathrm{CD} 4 / \mathrm{CD} 8$ ratio, hypogammaglobulinaemia, IgA deficiency, and a marked reduction of in vitro IgG production with variable IgM production. $^{2}$ A defective expression of all MHC class II antigens DR, DP, and DQ is the diagnostic hallmark. In some patients there was weak expression of MHC class II antigens on peripheral blood mononuclear cells that might explain why some antibody responses to fungi or viral antigens were retained. Antibodies to polysaccharides like blood group antigens $A$ or $\mathrm{B}$, or pneumococcal polysaccharides, have also been detected in some patients. ${ }^{2}$ The initiation of an immune response to protein antigens requires antigen uptake, degradation, and peptide presentation by MHC class II molecules, while for antibodies to polysaccharide antigens, $\mathrm{B}$ cell activation and maturation may be independent of MHC class II function. As many reported cases have had severe combined immunodeficiency and have

Table 2 Immunological findings at 1 year of age

\begin{tabular}{lrc}
\hline & Patient & Controls $^{\star}$ \\
\hline Proliferative responses $\dagger$ & & \\
Unstimulated (3 days) & 1300 & $678(275)$ \\
Phytohaemagglutinin $(1 \mu \mathrm{g} / \mathrm{ml})$ & 65200 & $48858(23523)$ \\
Pokeweed mitogen $(10 \mu \mathrm{g} / \mathrm{ml})$ & 29000 & $33081(22009)$ \\
OKT3 $(5 \mathrm{ng} / \mathrm{ml})$ & 3200 & $37366(15030)$ \\
Unstimulated (7 days) & 800 & $503(340)$ \\
Tetanus & 300 & $6194(9142)$ \\
Tuberculin PPD & 1500 & $8311(7135)$ \\
Candida & 1100 & $1263(1170)$ \\
Immunoglobulin production $\ddagger$ & 140 & $2201(1089)$ \\
IgG & 150 & $287(346)$ \\
IgA & 948 & $2658(1318)$ \\
IgM & &
\end{tabular}

${ }^{\star}$ Mean (SD) of 10 healthy adult controls. Eight, nine, and six of them exhibited a significant reactivity (stimulation index 23) towards tetanus, tuberculin purified protein derivative (PPD), or candida antigens respectively. In the 10 controls stimulated immunoglobulin production varied from 522 to $3582 \mathrm{ng} \mathrm{IgG/ml}$ and 300 to $3600 \mathrm{ng} \mathrm{IgM/ml}$.

† Values are counts/minute after ${ }^{3} \mathrm{H}$-thymidine uptake after three days for mitogen and seven days for antigen stimulation. $\ddagger$ Expressed as $\mathrm{ng} / \mathrm{ml}$ in supernatants after pokeweed mitogen stimulation $(0.1 \mu \mathrm{g} / \mathrm{ml})$ of $0.5 \times 10^{6}$ mononuclear cells $/ 500 \mu$ after eight days of culture in RPMI 16401640 medium (Gibco) supplemented with $10 \%$ fetal calf serum, glutamine, penicillin, and streptomycin. 
A

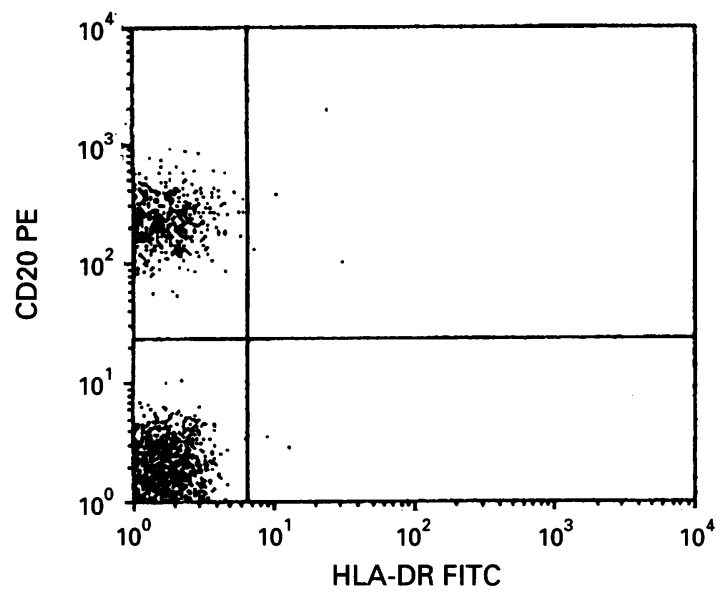

Patient

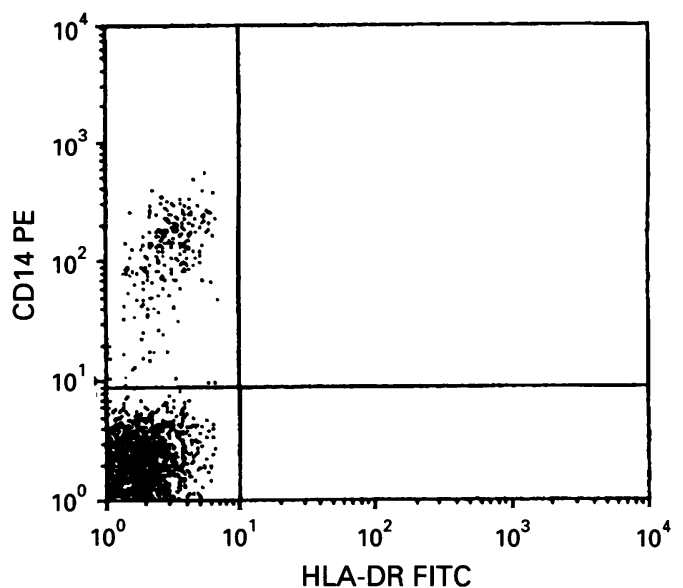

Control

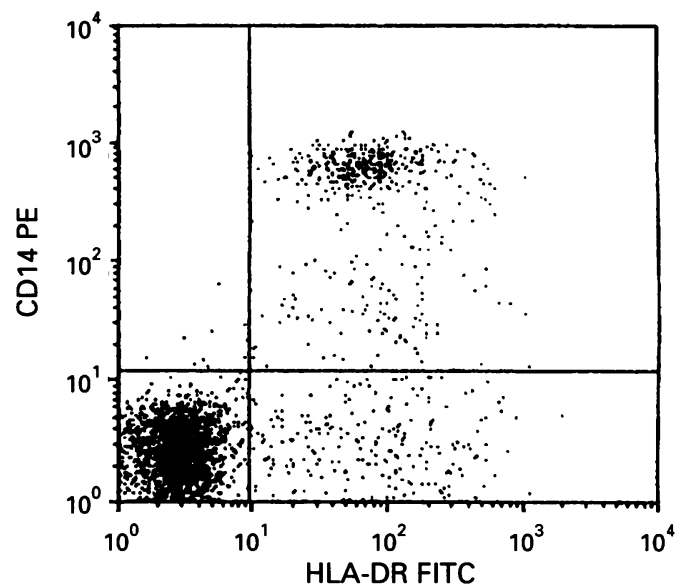

B

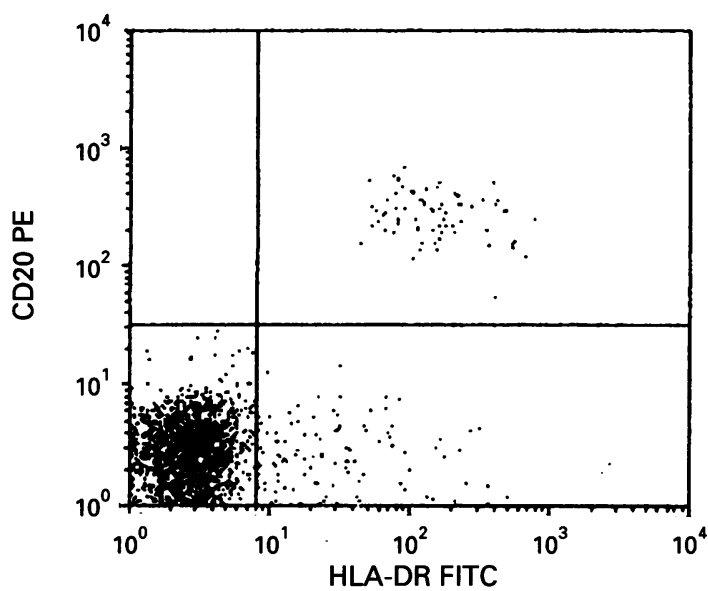

Lack of HLA-DR-expression on B cells and monocytes. HLA-DR expression of CD20+ B cells (yymphocyte gate) and $C D 14+$ monocytes (lymphocyte and monocyte gate) in peripheral blood of the child $(A)$ and a healthy control $(B) . B$ cells were stained with phycoerythrin labelled anti-CD20 antibodies and fluorescein isothiocyanate conjugated anti-HLA-DR antibodies (left side) and analysed by two colour immunofluorescence. Monocytes were stained by phycoerythrin labelled anti-CD14 antibodies and anti-HLA-DR antibodies (right side).

required bone marrow transplantation for survival, our patient appears to have a relatively benign type of MHC class II deficiency. She is still alive and stable on immunoglobulin replacement and co-trimoxazole prophylaxis.

Additional cases of MHC class II deficiency have been recently reported with manifestations of autoimmunity. ${ }^{14}$ Two patients had autoimmune haemolytic anaemia, which was associated with other autoantibodies such as antinuclear and antimitochondrial antibodies, antineutrophil and antismooth muscle antibodies. Our case had autoantibodies to the rhesus ' $e$ ' antigen that may have been induced through very low but undetectable amounts of MHC class II antigens, or possibly by $\mathrm{T}$ cell independent $\mathrm{B}$ cell activation by the rhesus blood group antigen, which is a small integral membrane protein whose structure is maintained by surrounding lipids but not carbohydrates. ${ }^{12} 15$ Another possibility is that the autoantibodies are produced by $\mathbf{B}$ cell clones that spontaneously arise in patients with deficient $T$ cell surveillance. In conclusion, the case report provides evidence that the stimulation and production of autoantibodies to proteins does not always require cellular interactions through $\mathrm{MHC}$ class II molecules.
1 Touraine JL, Betuel H, Suillet G, Jeune M. Combined immunodeficiency disease associated with absence of cell surface HLA A and B antigens. $\mathcal{F}$ Pediatr 1978; 93: 47-51.

2 Griscelli C, Lisowska-Grospierre B, LeDeist F, et al. Combined immunodeficiency with abnormal expression of MHC class II genes. Clin Immunol Immunopathol 1989; 50: S140-8.

3 Durandy A, Mangeney M, Griscelli C, Forveille M, LeDeist F, Fischer A. Activation of genetically major histocompatibility complex (MHC) class II deficient B lymphocytes. $\mathcal{f}$ Clin Immunol 1989; 9: 125-31.

4 Remy N, Grundhewer H, Stück B, Wahn U. Seltener primärer Immundefekt. Major-Histocompatibility-
Complex-Klasse II Antigendefekt. Pädiatrische Praxis 1991; 42: 315-23.

5 Lisowska-Grospierre B, Charron DJ, DePreval C, Durandy A, Griselli C, Mach B. A defect in the regulation of major histocompatibility complex class II gene expression in human HLA-DR negative lymphocytes from patients with combined immunodeficiency syndrome. $\mathcal{f}$ Clin Invest 1985; 76: 381-5.

6 Marcadet A, Dausset J, Cohen D, Fischer A, Durandy A, Griscelli C. HLA genotyping using DNA probes in two cases of combined immunodeficiency syndre with

7 Rijkers GT, Roord J, Koning F, Kuis W, Degers BJM. Phenotypical and functional analysis of B lymphocytes of two siblings with combined immunodeficiency and defectwo siblings with combined immunodeficiency and defec-
tive expression of major histocompatibility complex (MHC) class II antigens on mononuclear cells. $\mathcal{J}$ Clin (MHC) class II antigen

8 Clement LT, Plaeger-Marshall S, Haas, A, Saxon A, Martin AM. Bare lymphocyte syndrome: consequence of absent class II major histocompatibility antigen expression for B lymphocyte differentiation and function. $\mathcal{F}$ Clin Invest 1988; 81: 669.

9 Reith W, Herrero-Sanchez C, Kobr M, et al. MHC class II regulatory factor RFX has a novel DNA-binding domain and a functional independent dimerization domain. Genes Dev 1990; 4: 1528-40.

10 Kupfer A, Swain SL, Janeway CA, Singer SJ. The specific direct interaction of helper $T$ cells and antigen-presenting B cells. Proc Natl Acad Sci USA 1986; 83: 6080. 
11 Benaceraf B. Role of $\mathrm{MHC}$ gene products in immune regulation. Science 1981; 212: 1229-38.

12 Cartron JP, Agre P. Rh blood group antigens: protein and gene structure. Semin Hematol 1993; 30: 193-208.

13 Wahn V, Yokota S, Meyer KL, et al. Expansion of a maternally derived monoclonal $T$ cell population with CD3 $+/ \mathrm{CD} 8+/ \mathrm{T}$ cell receptor $\gamma / \delta+$ phenotype in a child with severe combined immunodeficiency, $f$ Immunol 1991; 147: 2934-41.
14 Klein C, Lisowska-Grospierre B, LeDeist F, Fischer A, Griscelli C. Major histocompatibility complex class II deficiency: clinical manifestations, immunological features, and outcome. $f$ Pediatr 1993; 123: 921-8.

15 Moore S, Woodrow CF, McClelland DBL. Isolation of membrane components associated with human red cell antigens $\mathrm{Rh}(\mathrm{D}),(\mathrm{c}),(\mathrm{E})$ and Fya. Nature 1982; 295: 529-31. 